\section{Cetus retains PCR patents}

\section{San Francisco}

Cetus Corporation has finally nailed down its lucrative patent on the revolutionary polymerase chain reaction (PCR) technology. Last week, a US District Court upheld the validity of the patents granted to the biotechnology company against a challenge by the chemical giant Du Pont.

Although the decision came as no surprise to biotechnology observers, it was nonetheless welcome news to Cetus, whose financial health depends in large part on its rights to the PCR technology. The victory was especially important to the company in the light of the major blow it received last summer, when the US Food and Drug Administration unexpectedly failed to recommend market approval for interleukin-2, its anticancer drug.

The six-week jury trial, which included testimony from three Nobel laureates, examined the origins of PCR, a 'gene amplification' technique. PCR is basically a method of detecting and serially reproducing specific gene fragments from a pool of DNA. It has dramatically transformed many areas of biological research since its introduction in 1985, and has also been used to identify criminals from blood samples, examine archaeological remains and diagnose infections and diseases.

In the trial, Cetus maintained that PCR was invented by its scientist Kary Mullis and was not practised anywhere until Cetus announced it in a 1985 paper. Cetus's patent rights to PCR were first issued in 1987, and were confirmed by a US Patent and Trademark Office re-examination last year.

Du Pont, however, contended that the process was made obvious by the work of Massachusetts Institute of Technology professor and Nobel laureate H. Gobind Khorana and his colleagues in the early 1970s. Two of Khorana's papers and a grant application were presented as evidence by $\mathrm{Du}$ Pont, although Khorana declined to testify.

Instead, Du Pont presented as witnesses Stanford University Nobellist Arthur Kornberg and several of Khorana's postdocs from the 1970s, while Cetus countered with testimony from Nobel prizewinners Hamilton Smith of Johns Hopkins University and Sir Aaron Klug of the UK Medical Research Council.

A Du Pont attorney said last week that the company is "reviewing all its options" regarding the decision. A separate phase of the trial, scheduled to begin next week, will consider the Cetus countercharge that Du Pont has infringed upon another PCR-related patent; in that phase, Cetus will seek damages from Du Pont as well as an injunction against Du Pont sales of materials it considers to be PCR technology.

The markets for PCR technology are expected to grow enormously in the next few years. A Cetus joint venture with Perkin-
Elmer Corporation, which sells PCR equipment and reagents to research laboratories, resulted in sales of \$26 million last year. In addition, Cetus has licensed PCR to Hoffmann-La Roche and others to develop diagnostics kits which may be used for a variety of medical purposes including detection of cancers, AIDS and genetic disorders, as well as for forensic identifications. Analysts estimate that the combined PCR market may reach $\$ 400$ million within five years.

Now that Cetus's rights to that market appear safe, Cetus attorney Peter Staple believes the victory has implications for other biotechnology firms as well. "Patents can be an equalizer", he says. They can allow young, relatively small companies to protect their results from big corporations in the still-unpredictable field of biotechnology. \section{CITATION ANALYSIS US science OK}

WHILE US science advocates argue that US science is losing ground to the rest of the world, new data from the Institute for Scientific Information (ISI) appear to suggest otherwise. During the past decade, the United States has not only improved nearly 7 per cent in the relative quality of its science (as measured by average citations per US paper compared to the worldwide average), but is also improving faster than any of the other Group of Seven (G-7) nations. The data also show an apparent correlation between funding and science quality. Research budgets in the United States, Japan, Germany and France whose research has improved relative to the rest of the world - have consistently grown over the decade, while Britain and Canada - whose research quality has slipped over the past five years - have been hit by budget cutbacks.

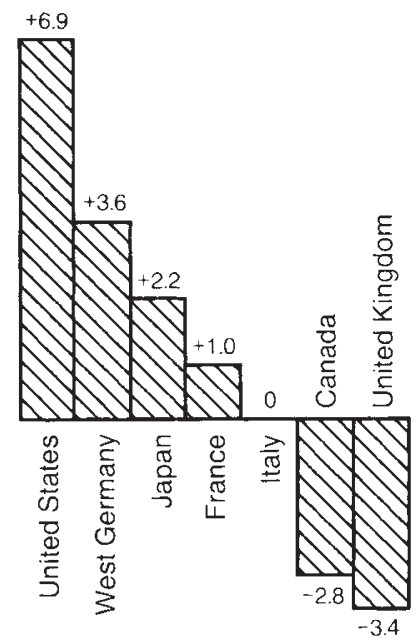

Research quality of the G-7 nations, expressed as percentage change in citations per paper from 1981-85 to 1986-90, relative to the world average in both years. Source: ISI.

\section{Education under threat}

\section{London}

THE quality of UK undergraduate education will be damaged if the Universities Funding Council (UFC) continues to insist that universities take on more students, despite the fact that not all of these will be funded, warns the Committee of Vice-Chancellors and Principals (CVCP).

The UFC said last week that it will fund 303,700 undergraduates in 1991-92, some seven per cent more than in 1990-91. But the universities' four-year plans, submitted to the UFC last summer, had requested

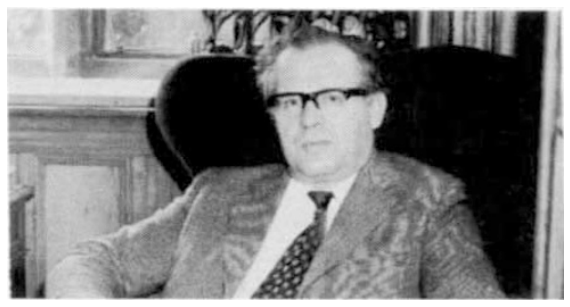

Sir Peter Swinnerton-Dyer - grant calculator. 335,000 students in 1991-92. A covering letter from Sir Peter Swinnerton-Dyer, chief executive of UFC, sent to each university to explain how its grant had been calculated, says that the UFC expects universities to admit significant numbers of students without funding from the UFC. Most vicechancellors regard this as a thinly veiled threat. They say that universities that refuse to expand will be discriminated against in future years when the UFC comes to distribute its budget.

Sir Edward Parkes, chairman of the CVCP, says that this unfunded expansion will mean a decline in the quality of UK undergraduate university education. His comments reflect the official position adopted by the vice-chancellors at their meeting last Friday. But Sir Graham Hills, from Strathclyde University, a long-standing dissident in the vice-chancellors' ranks, says that universities have been claiming for ten years that underfunding will produce an imminent decline in undergraduate education.

Most vice-chancellors accept that the government is unlikely over the next few years to give the UFC sufficient money to fund the desired expansion in full. Last autumn, there was much speculation that some universities would be forced to charge students 'top-up' fees to maintain teaching qualty. This would be extremely unpopular with students, and Hills believes the 'political odium' of fees will deter universities from introducing any charges for at least another year. Sir John Kingman, vice-chancellor of the University of Bristol, says the opposition to top-up fees, from the government, as well as from students, means they are unlikely for the 'foreseeable future'.

British university funding has been shrouded in uncertainty since last autumn, 
when the UFC's new 'competitive bidding' system for funding undergraduate teaching was suspended (see Nature 348, 3; 1 November 1990). Under this system, universities told the UFC how many students they wished to teach by 1994-95, and how much this would cost.

The UFC's logic was that the universities, most of which wish to expand, would compete against each other to take on more students at a reduced cost per student. This would have met the government's twin policy aims of expanding higher education and driving down the average cost of teaching. But university vice-chancellors submitted the vast majority of their bids for more students at the maximum 'guide prices' suggested by the UFC, forcing the UFC to withdraw the system. The UFC says it will unveil a replacement system, which will retain 'an element of competition' between the universities for funds, later this month.

A similar bidding system to that which failed in the universities was introduced for polytechnic funding a year earlier, and the polytechnics have co-operated until now.
But the Commitee of Directors of Polytechnics has now followed the CVCP's lead and declared that further efforts to drive down the cost of teaching each student will undermine teaching quality.

The rejection of the bidding systems across both universities and polytechnics is significant because a merger between their funding bodies is becoming an increasingly likely prospect. The vice-chancellors' argument that further reducing teaching costs will undermine quality would have been hard to sustain in a merged system for higher education funding, if the polytechnics had continued to further improve their efficiency without complaint.

Swinnerton-Dyer told the House of Lords Science and Technology Committee last week that he believes a merger between the UFC and the Polytechnics and Colleges Funding Council (PCFC), at least of their support for teaching, is 'inevitable'. The PCFC is expected this week to approve plans to make its methods of funding more similar to those of the UFC - an important first step in any merger plan.

Peter Aldhous

\section{INDUSTRIAL INNOVATION}

\section{Get academics into the boardroom}

\section{London}

INCREASED links between academic scientists and industry, including the appointment of university and polytechnic staff to company boards, are recommended today (7 March) as a central plank of the UK House of Lords Science and Technology (S\&T) Committee's strategy to revive British industry.

The Lords applaud the efforts that higher education institutes and research council laboratories have taken already to promote technology transfer to industry, although they say that the transfer of technology from government departmentfunded laboratories has been disappointing. Their report also warns that the government should not use increased academic collaboration with industry as an excuse to reduce further its funding for the UK science base.

The S\&T committee's inquiry into innovation in British industry was prompted by the lack of investment in British industry during the $1980 \mathrm{~s}$, and the consequent decline in the manufacturing sector. Its report paints a gloomy picture, concluding that British industry is caught within a "vicious circle" of financial disincentives to investment.

The government should take a leading role in recreating a favourable climate for innovation in the United Kingdom, the report says. The government's policy over the past few years of reducing its funding for the development of commercial products and the failure of British public spending on research and development (R\&D) to keep pace with that of our industrial competitors - is sending "the wrong signals" to industry, the Lords say.

During the past few months, the UK government has implicitly acknowledged these concerns, launching a three-year, $£ 32$-million grant scheme to promote $R \& D$ in small companies and changing the rules of its LINK research programme, which promotes industrial-academic collaboration in $R \& D$, to encourage more companies to take part. But these changes are likely to have a limited effect, and the S\&T committee's report notes that the Department of Trade and Industry's spending on industrial innovation was slashed by more than one half between 1985-86, when $£ 283$ million was spent, and 1990-91. The mid-1980s budget should be restored, the report says.

The "short-termism" of industrial companies themselves is similarly berated by the S\&T committee. British companies invest too little in $R \& D$, ploughing too much of their profits into dividends for their shareholders, the report says. Investment in $R \& D$ is further constrained by the fear that companies reinvesting a large proportion of their profit will be less able to fight off hostile take-over bids.

Investment in $R \& D$ could be increased by changing the UK tax laws. At present, companies are allowed to write off the full value of their annual investment in $R \& D$ against tax. The S\&T committee argues that companies' R\&D spending could be increased by making 150 per cent of the increase in a company's R\&D spending from one year to the next exempt from tax. Australia introduced a similar measure in 1985, and R\&D spending has since increased.

PeterAldhous

\section{What's in it for science?}

\section{London}

IN general, British science students do not fare as well as other undergraduates in the recently announced 1991-92 budget from the UFC (see opposite).

While the UFC has announced a 7 per cent increase in funding for all undergraduate teaching over 1990-91, the number of students in the physical sciences will grow by only 5.4 per cent, and fewer agricultural scientists, engineers and technologists will be funded than in the previous year. But biological sciences, with a 14.1 per cent increase, has bucked the trend.

The arts and humanities are expanded to a greater extent. Sir Peter Swinnerton-Dyer, UFC chief executive, says that the decisions were made "on the basis of apparent student demand"

The allocations also show that the UFC's research money is now being distributed more selectively, becoming concentrated in those universities which achieve the best research records. Swinnerton-Dyer told the House of Lords Science and Technology Committee last week that not all of Britain's universities can claim to be important centres for research, and the UFC can no longer afford to fund them all as such.

The idea of "teaching-only" universities was suggested by the Advisory Board for the Research Councils in 1987, but was eventually dropped from the government's plans to reform higher education in 1988 after protest from the universities. The UFC says that teaching-only universities are not on its immediate agenda, but goes on to add that individual universities may wish to spend their research money more selectively, and concentrate on teaching alone in specific subjects.

John Ashworth, director of the London School of Economics, says that separating teaching funds from research is "administratively convenient", but he argues that research spending in the universities helps to maintain teaching quality, because research students and postdoctoral researchers are involved in teaching.

The allocations do contain one piece of welcome news for university science. Last month, the UFC told the universities that it is planning to spend $\mathfrak{£} 70$ million over three years to upgrade university animal facilities to make them comply with tough new standards for laboratory animal housing introduced in 1989, unexpectedly meeting the universities' requests for money almost in full (see Nature 345, 755; 28 June 1990). The universities will receive $£ 35$ million in 1991-92. John Bleby, from the Royal Veterinary College, London, says that the new money is "a terrific break for the animals", as well as for biomedical research.

Peter Aldhous 